\title{
PENERAPAN METODE PEMBELAJARAN BEACH BALL (BOLA PANTAI) DALAM KETERAMPILAN BERBICARA BAHASA JERMAN SISWA
}

\author{
Tahmi $^{1}$ dan Nurming Saleh ${ }^{2}$ \\ Fakultas Bahasa dan Sastra. Universitas Negeri Makassar \\ E-mail : tahmiindah@gmail.com ${ }^{1}$
}

\begin{abstract}
ABSTRAK
Penelitian ini merupakan penelitian tindakan kelas yang bertujuan untuk mengetahui perencanaan, proses, dan hasil metode pembelajaran beach ball (bola pantai) dalam keterampilan berbicara bahasa Jerman siswa. Data penelitian ini terdiri atas dua jenis, yaitu: data kualitatif dan data kuantitatif. Data kualitatif diperoleh melalui observasi, dan data kuantitatif diperoleh melalui tes keterampilan berbicara siklus I dan siklus II. Data dianalisis dengan menggunakan teknik persentase. Hasil penelitian menunjukkan bahwa keterampilan berbicara dengan persentase nilai yang diperoleh siswa pada siklus I mencapai 60,66\%, dan siklus II mencapai 78,25\%. Hasil ini menunjukkan bahwa penerapan metode pembelajaran beach ball meningkat dalam keterampilan berbicara bahasa Jerman siswa.
\end{abstract}

\section{Kata Kunci: Keterampilan Berbicara, Beach Ball, Bahasa Jerman}

\section{ABSTRACT}

This research is a classroom action research which aims to find out the planning, process, and results of beach ball learning methods in students' German speaking skills. The research data consists of two types, namely: qualitative data and quantitative data. Qualitative data is obtained through observation, and quantitative data is obtained through the first cycle and second cycle speaking skills tests. Data were analyzed using percentage techniques. The results showed that speaking skills with the percentage of grades obtained by students in the first cycle reached $60.66 \%$, and the second cycle reached $78.25 \%$. These results indicate that the application of the beach ball learning method increases in students' German speaking skills.

\section{Keywords: Speaking Skill, Beach Ball, German Language}

\section{PENDAHULUAN}

Pengajaran bahasa Jerman merupakan salah satu bahasa asing yang diajarkan pada tingkat SMA/SMK/MAN. Ada empat keterampilan dalam bahasa Jerman yang harus diajarkan yaitu, keterampilan menyimak (hören), berbicara (sprechen), membaca (lesen), dan menulis (schreiben). Salah satu keterampilan yang diajarkan dalam pengajaran bahasa Jerman di SMA/SMK/MAN adalah keterampilan berbicara (sprechen). Berdasarkan observasi yang telah dilakukan di SMA Negeri 2 Majene diperoleh informasi bahwa sebagian besar siswa mengalami kesulitan dalam berbicara bahasa Jerman. Hal ini dibuktikan dengan hasil nilai ulangan harian siswa. Masalah ini terjadi diduga karena kurangnya variasi atau metode yang digunakan guru saat mengajar sehingga siswa tidak tertarik dan merasa cepat bosan dalam mengikuti pelajaran bahasa Jerman. 
Metode dan pembelajaran merupakan satu kesatuan yang .saling berkaitan dalam mencapai tujuan pembelajaran yang efektif dan menyenangkan. Salah satu unsur yang paling penting dalam pembelajaran adalah penerapan sebuah metode pembelajaran yang efektif, kreatif dan inovatif yang mampu memfasilitasi siswa dalam meningkatkan keterampilan berbahasanya. Hal tersebut sejalan dengan pendapat Djamarah (2006:46) yang mengemukakan bahwa metode pembelajaran adalah suatu cara yang dipergunakan untuk mencapai tujuan yang telah ditetapkan.

Beberapa

penelitian

telah

membuktikan bahwa model pembelajaran dapat berpengaruh positif pada hasil belajar dan motivasi akademik peserta didik. (Quddus, 2017; Mantasiah et all, 2017;2018, Yusri et all, 2018; Qalbi, 2017; Romadloni et all, 2017). Selain model pembelajaran, media pembelajaran juga dapat berpengaruh positif pada hasil belajar peserta didik (Zulfikar et all, 2017; Tenri et all, 2017, Jufri, 2017;2007).

Metode pembelajaran disusun dan kemudian diaplikasikan. Senada dengan hal tersebut, Mukrimah

(2014:50) mengemukakan bahwa metode pembelajaran dapat diartikan sebagai cara yang digunakan untuk mengimplementasikan rencana yang sudah disusun dalam bentuk kegiatan nyata dan praktis untuk mencapai tujuan pembelajaran. Sejalan dengan pendapat tersebut, Suyono dan Hariyanto (2015:19) menyatakan bahwa metode pembelajaran adalah seluruh perencanaan dan prosedur maupun langkah-langkah kegiatan pembelajaran termasuk pilihan cara penilaian yang akan dilaksanakan. Metode pembelajaran dapat dianggap sebagai sesuatu prosedur atau proses yang teratur, suatu jalan atau cara yang teratur untuk melakukan pembelajaran.

Rumusan masalah dalam penelitian ini adalah bagaimana perencanaan, proses dan hasil pembelajaran keterampilan berbicara bahasa Jerman siswa kelas XI Bahasa SMA Negeri 2 Majene melalui metode pembelajaran Beach Ball. Metode pembelajaran Beach Ball merupakan metode pembelajaran dalam meningkatkan keterampilan berbahasa khususnya keterampilan berbicara. Metode ini juga membantu siswa agar lebih percaya diri untuk berbicara dan dapat mengontrol siswa selama berjalannya proses pembelajaran. Sejalan dengan hal tersebut, Riau (2011:8) menyatakan bahwa metode Beach Ball adalah metode pembelajaran yang melibatkan antara guru dan siswa untuk saling bertukar pendapat tentang suatu permasalahan bersama-sama guna mencari pemecahan permasalahan. Senada dengan pendapat tersebut, Rudy (2013:946) menyatakan bahwa metode pembelajaran Beach Ball adalah pembelajaran yang melibatkan antara guru dan siswa untuk saling bertukar pendapat tentang suatu permasalahan secara bersama-sama guna mencari pemecahan permasalahan tersebut berdasarkan kebenaran dengan pelaksanaan guru memberi bola kepada salah seorang siswa untuk memulai diskusi dengan pengertian hanya siswa yang memegang bola yang boleh berbicara.

Al-Tabany (2014) mengemukakan bahwa metode Beach Ball berarti guru memberi bola kepada salah seorang siswa untuk memulai diskusi, dengan pengertian bahwa hanya siswa yang memegang bola yang boleh berbicara. Siswa lain mengangkat tangan agar mendapat bola jika ingin mendapat giliran berbicara. Berdasarkan 
uraian tersebut, disimpulkan bahwa metode pembelajaran Beach Ball adalah metode pembelajaran yang menggunakan bola pantai melibatkan guru dengan siswa dan siswa dengan siswa lainnya melalui proses tanya jawab. Kekuatan dalam suatu metode pembelajaran terletak pada langkah-langkah dalam penerapannya. Sani (2016:233-234) mengemukakan bahwa langkah-langkah metode pembelajaran Beach Ball sebagai berikut: (1) guru menyampaikan tujuan pembelajaran dan topik yang akan didiskusikan; (2) guru mempersiapkan sebuah bola, kemudian memberikannya kepada seorang peserta didik yang diminta untuk mulai diskusi; (3) peserta didik lain yang ingin berbicara harus mengangkat tangan untuk meminta bola dan berbicara jika bola telah dipegangnya; (4) diskusi dilanjutkan sampai batas waktu yang telah ditetapkan; (5) guru membimbing peserta didik membuat kesimpulan; (6) guru melakukan evaluasi pada akhir pembelajaran.

Metode pembelajaran Beach Ball (Bola Pantai) memiliki beberapa kelebihan dan kekurangan dalam penerapannya, sebagaimana yang dikemukakan oleh Alma (2008:56) bahwa kelebihan metode pembelajaran Beach Ball sevagai berikut: (a) suasana kelas akan lebih terorganisir sebab siswa hanya fokus pada kegiatan; (b) menyadarkan siswa bahwa masalah dapat dipecahkan dengan berbagai jalan. (c) membiasakan siswa mendengarkan pendapat orang lain sekalipun berbeda dengan pendapatnya; (d) dapat meningkatkan prestasi kepribadian individu seperti toleransi, demokratis, kritis, berfikir sistematis dan membuat siswa lebih aktif; (e) kesimpulan-kesimpulan diskusi mudah dipahami karena siswa mengikuti proses berfikir sebelum sampai kepada kesimpulan.
Sedangkan Kekurangan metode pembelajaran Beach Ball sebagai berikut: (a)kadang-kadang bisa terjadi adanya pandangan berbeda dari berbagai siswa; (b) dalam diskusi menghendaki pembuktian logis, yang tidak terlepas dari faktor-faktor dan tidak merupakan jawaban yang hanya dugaan atau coba-coba saja; (c) tidak dapat dipakai dalam kelompok yang besar; (d) siswa mendapat informasi yang terbatas; (e) mungkin dikuasai oleh orang-orang yang suka berbicara.

\section{METODE PENELITIAN}

Penelitian ini merupakan penelitian tindakan kelas (Classroom Action Research). Model yang digunakan dalam penelitian ini adalah model John Elliot. Penelitian ini dilaksanakan di kelas XI Bahasa SMA Negeri 2 Majene Kabupaten Majene, Provinsi Sulawesi Barat. Teknik pengumpulan data dalam penelitian ini menggunakan observasi dan tes. Observasi dilakukan untuk mengamati secara langsung bagaimana hasil belajar siswa selama proses pembelajaran berlangsung. Dalam penelitian ini observasi dilakukan terhadap guru dan siswa selama penelitian tindakan kelas dilakukan. Adapun alat yang digunakan untuk mengamati kegiatan guru dan siswa adalah lembar Observasi Guru dan siswa. Observasi terhadap guru dilakukan dengan menggunakan lembar observasi. Sedangkan observasi terhadap siswa dilakukan dengan menggunakan lembar observasi.

\section{HASIL DAN PEMBAHASAN}

Berdasarkan penilaian terhadap sikap dan keaktifan siswa selama proses pembelajaran diperoleh data bahwa pada siklus I siswa yang merespon positif terhadap metode pembelajaran yang digunakan oleh guru sebanyak 75,92\% dan siklus II 94,44 
$\%$. Siswa yang mendengarkan penjelasan guru dengan baik dan seksama pada siklus I sebanyak 77,77 \% dan sebanyak 92,59\% pada siklus II. Siswa yang aktif dalam mengikuti kegiatan pembelajaran pada siklus I sekitar 68,51 \% dan pada siklus II mengalami peningkatan sekitar 94,44\%. Siswa aktif berpartisipasi dalam kerja kelompok 62,96\% pada siklus I dan 79,62\% juga mengalami peningkatan pada siklus II. Siswa yang menanyakan tentang hal-hal yang belum dipahami atau kosakata baru yang mereka temukan $61,11 \%$ dan pada siklus II $94,44 \%$.

Sedangkan penilaian terhadap tingkat pengetahuan siswa diperoleh data bahwa pada siklus I siswa yang menjawab pertanyaan guru dan menghubungkan materi yang lalu dengan materi yang akan dipelajari $75,92 \%$ dan pada siklus II meningkat sebanyak 94,44 \%. Siswa yang dapat menyebutkan dan melafalkan dengan kalimat lengkap dalam bahasa Jerman 74,07 \% dan siklus II sekitar 94,44\%. Siswa yang melakukan tanya jawab dengan teman sebangkunya berdasarkan pengalaman siswa sendiri sebanyak $72,22 \%$ dan pada siklus II menjadi 98,14\%. Siswa yang membuat kesimpulan dari materi yang baru saja dipelajari $61,11 \%$ dan siklus II sebanyak $85,18 \%$. Siswa yang menyampaikan kesimpulan materi yang telah dibuat sekitar $59,25 \%$ dan pada siklus II mengalami peningkatan sebanyak $85,18 \%$.

Hasil keterampilan berbicara bahasa Jerman siswa kelas XI bahasa pada siklus I yaitu $60,66 \%$ dan termasuk dalam kategori cukup. Sedangkan pada siklus II mengalami peningkatan yakni $78,25 \%$ dan termasuk dalam kategori baik. Berdasarkan hasil penelitian tersebut menunjukkan bahwa penerapan metode pembelajaran Beach Ball dalam keterampilan berbicara bahasa Jerman siswa kelas XI Bahasa SMA Negeri 2 Majene dinyatakan meningkat dan telah mencapai Kriteria Ketuntasan Minimal (KKM).

\section{KESIMPULAN}

Berdasarkan hasil penelitian, maka dapat disimpulkan bahwa perencanaan pembelajaran dalam keterampilan berbicara bahasa Jerman melalui metode pembelajaran Beach Ball (Bola Pantai) siswa kelas XI Bahasa SMA Negeri 2 Majene telah terlaksana dengan baik. Proses pembelajaran keterampilan berbicara bahasa Jerman siswa kelas XI Bahasa SMA Negeri 2 Majene mengalami peningkatan baik dari segi kognitif dan afektif siswa. Hasil evaluasi keterampilan berbicara bahasa Jerman siswa kelas XI Bahasa SMA Negeri 2 Majene melalui metode pembelajaran Beach Ball dinyatakan meningkat, hal ini dibuktikan dengan nilai rata-rata pada siklus I yaitu 60,66 sedangkan nilai rata-rata pada siklus II mencapai 78,25 dengan perbandingan skor rentangan yang diperoleh antara sikus I dan siklus II yaitu 17,59 dan hasil evaluasi pada siklus II dinyatakan telah menacapai Kriteria Ketuntasan Minimal (KKM).

\section{DAFTAR PUSTAKA}

Alma, Buchari. (2008). Guru Profesional Menguasai Metode dan Terampil Mengajar. Bandung: Alfabeta.

Al-Tabany, Trianto Ibnu Badar. (2014). Mendesain Model Pembelajaran Inovatif, Progresif Dan Kontekstual. Jakarta: Kencana

Arikunto, Suharsimi. (2013). Dasar-Dasar Evaluasi Pendidikan. Jakarta: PT Bumi Aksara. 
Baureis, David. (2013). Eine Methode zur Identifikation erforderlicher

Kompetenzen für hibryde Leistungsbündel. Bremen: EHV.

Djiwandono, Soenardi. (2008). Tes Bahasa: Pegangan Bagi Pengajar Bahasa. Jakarta: PT Indeks.

Haling, Abdul dkk. (2007). Belajar dan Pembelajaran. Makassar: Badan Penerbit UNM.

Mukrimah, Syifa Siti. (2014). Metode Belajar dan Pembelajaran. Bandung: UPI.

Nurjamal, Daeng dkk. (2015). Terampil Berbahasa. Bandung: Alfabeta.

Ratna, Nyoman Kutha. (2012). Teori, Metode, dan Teknik Penelitian Sastra. Yogyakarta: Pustaka Pelajar.

Rusman. (2011)

Model-Model

Pembelajaran: Mengembangkan

Profesionalisme Guru. Jakarta: Rajawali Pers.

Sahabuddin. (2007). Mengajar dan Belajar. Makassar: Badan Penerbit Universitas Negeri Makassar.

Sani, Ridwan Abdullah. (2016). Inovasi Pembelajaran. Jakarta: PT Bumi Aksara.

Schelle, Carla dkk. (2010). Unterricht als Interaktion: Ein Fallbuch für die Lehrerbildung. Kempten: Julius Klinkhardt.

Suyono dan Hariyanto. (2015). Belajar dan Pembelajaran Teori Konsep Dasar. Bandung: PT Remaja Rosdakarya.

Taniredja, Tukiran dkk. (2013). ModelModel Pembelajaran Inovatif dan Efektif. Bandung: Anggota Ikatan Penerbit Indonesia (IKAPI).

Tarigan, Henry Guntur. (2008). Berbicara Sebagai Suatu Keterampilan
Berbahasa. Bandung: Percetakan Angkasa.

JUFRI, J. (2007). Metode Penelitian Bahasa, Sastra dan Budaya.

Jufri, J. (2007). Metode Penelitian Bahasa. Sastra dan Budaya.

JUFRI, J. (2017). Strategi Pembelajaran Bahasa.

Qudus, M., \& Yusri, Y. (2017). Keefektifan Penggunaan Metode Audio Lingual dalam Pembelajaran Kemampuan Menyimak Bahasa Jerman. Indonesian Journal of Educational Studies, 20(2).

Mantasiah, R., Juffri, J., \& Yusri, Y. (2017). Keefektifan Model Pembelajaran Jaring Laba-Laba (Webbed) dalam Keterampilan Menulis Karangan Sederhana Bahasa Jerman. Indonesian Journal of Educational Studies, 20(2).

Mantasiah, R. (2018, June). Pay It Forward Model in Foreign Language Learning to Increase Student's Self Efficacy and Academic Motivation. In Journal of Physics: Conference Series (Vol. 1028, No. 1, p. 012178). IOP Publishing.

Zulfikar, Z., \& Azizah, L. (2017). Keefektifan Penggunaan Media Pembelajaran Kartu Kuartet Dalam Pembelajaran Keterampilan Berbicara Bahasa Jerman Siswa Kelas Xi Ma Negeri 1 Makassar. Eralingua: Jurnal Pendidikan Bahasa Asing dan Sastra, 1(2).

Tenri, A., Asri, W. K., \& Azizah, L. (2017). Keefektifan Penggunaan Media Brettspiel Dalam Keterampilan Berbicara Bahasa Jerman Siswa Kelas X Sma Negeri 11 Makassar. Eralingua: Jurnal Pendidikan Bahasa Asing dan Sastra, 1(1).

Romadloni, A., \& Mantasiah, R. Intercultural approach in foreign language learning 
to improve students' motivation. Senior Editors, 61.

Yusri, Y., Mantasiah, R., \& Jufri, J. (2018).

The Use Of Two Stay Two Stray Model in English Teaching to Increase Student's Learning Outcome. Journal Of Advanced English Studies, 1(1), 3943.

Qalbi, U. N., Mantasiah, R., Jufri, J., \& Yusri, Y. (2017). Efektivitas Model Pembelajaran Kooperatif Tipe Teams Games Tournaments dalam Keterampilan Menulis Bahasa Jerman Siswa Kelas XII IPA SMA Negeri 1 Bontonompo Kabupaten Gowa. Indonesian Journal of Educational Studies, 20(1). 